\title{
TEACHERS' PERCEPTION OF AGGRESSIVE BEHAVIOUR IN CHILDREN: CASE OF BOSNIA AND HERZEGOVINA
}

\author{
Senija Tahirović, \\ International Univeristy of Sarajevo, Bosnia and Herzegovina.
}

\begin{abstract}
Aggressive behaviour in children and youth is a widespread phenomenon. Antisocial behaviour that includes certain kind of aggressive behaviour can occur and disappear again during a child's development. However, from a psychological perspective aggression can be one of the problematic types of behaviour in children with long-lasting negative consequences. The aim of this research paper is to examine teachers' perceptions of the types of aggressive behaviour as well as to find out the causes for the development of aggressiveness in school-age children in Bosnia and Herzegovina $(\mathrm{BiH})$ from the teacher's point of view. In order to define and classify the types of aggressive behavior in school age children in $\mathrm{BiH}$, the descriptive method was used. In order to understand aggressive phenomena and to identify their cause(s), the explanatory method was used. In order to examine teachers' perceptions of the types of aggressive behaviour as well as the causes for the development of aggressiveness, assessment scales for teachers' perceptions were used. The research findings indicate that proactive, reactive, and relational types of aggression are most often seen in school-age children from teachers' perceptions. The causes of aggressive behaviour range widely: Aggressive behaviour occurs as a combination of internal impulses and external stimuli or triggers that indicate possible aggression, so temperament as well as environmental factors can influence the development of aggressiveness; aggressive behaviour is acquired through learning by observing and imitating a model; the role of parents and their way of disciplining a child is another important cause; finally, mass media is seen as important cause of aggressive behaviour.
\end{abstract}

Keywords: Teacher; Child; Aggressiveness; Development and Perception 


\section{Introduction}

Aggressive behaviour in children and youth is a widespread phenomenon worldwide and in Bosnia and Herzegovina (BiH). We usually pay special attention to this issue when aggressive behaviour by children causes serious material damage or physical or emotional harm to a victim of aggression. Bosnia and Herzegovina is a specific context that is characterized by a variety of features including its post-war transformation in the spheres of economic development, the reconstruction of destroyed cities, state-building and the democratisation of society, fostering reconciliation and overcoming war trauma. Increasing news about the extremely aggressive behaviour of young people who commit murder, perform physical violence against children, emotionally abuse their peers or engage in serious crimes has raised serious concern for Bosnia-Herzegovina.

For children and youth, the term 'aggression' is usually used for behavioural disorders or problems. In adults, these behaviours are specified as antisocial disorders or personality disorders. When we talk about children, the term aggression may be used when a child breaks social norms and rules, whereas the behaviour of autistic children, for example, are not classified with this term (Delfos, 2008). According to Krahe, Baron and Richardson (2001) the term aggression describes any form of behaviour directed toward the goal of harming or injuring another living being who is motivated to avoid such treatment. Aggression is 'behaviour perpetrated or attempted with the intention of harming another individual physically or psychologically' (Bartol, 1995). Therefore, aggression has been defined as category of behaviour that causes or threatens physical harm to others. So aggression is not used as a unitary term but encompasses a variety of behaviours including verbal aggression, physical assault, homicide, destruction of objects, violence against humans and animals and other behaviour with the intention to cause pain and harm to victims.

From a psychological perspective, aggression is one of the problematic types of behaviour in children and youth in which two widely accepted behavioural syndromes can be recognised, as follows (Essau and Conradt 2004, Achenbach, 1993):

a) Externalising behaviour which includes uncontrolled types of behaviour such as hyperactivity, aggressiveness, and delinquency.

b) Internalising behaviour characterised by over-controlled behaviour (anxiety, depression, social withdrawal)

From a psychiatric perspective two diagnostic handbooks are usually used to explain and diagnose aggressive behaviour: the World Health Organisation's International 
Statistical Classification of Diseases and Related Health Problems (ICD 10, 1992), specifically Chapter V: Mental and behavioural disorders, and the American Psychiatric Association's Diagnostic and Statistical Manual of Mental Disorders (DSM). According to DSM-IV (1994) classification, aggression and antisocial behaviour are related to oppositional defiant disorders. DSM-V (2013) explains aggression as a part of disruptive, impulsive-control, and conduct disorders that include behaviors that violate the rights of others and/or that bring the individual into significant conflict with societal norms or authority figures. The lack of self-control, both in terms of emotions and behaviors are underlined as the main causes of the problems.

One of the concepts of aggressive behaviour introduces a new category of behavioural disorders (Delfos, 2008) which distinguish between conduct disorders and conduct problems. Conduct disorders, according to this concept, are related to genetic predisposition and the process of growing up, while conduct problems are caused by environmental factors. Making a distinction between conduct disorders and conduct problems is an issue of the dominance of one or another influence. As in the above-mentioned dilemmas to identify the intention of a child acting aggressively, determining a genetic predisposition or environmental factors is equally difficult, in particular when considering the child's normal process of growing up, development of the nervous system and the constant interaction of other environmental factors (Tahirović, 2011).

Because of the diversity of the causes and consequences of aggressive behaviour, there is a need to observe different types and expressions. Krahe (2001) presents one typology of aggressive behaviour in the following table.

Table 1. Types and expressions of aggressive behaviour

\begin{tabular}{|l|l|}
\hline Response modality & Verbal vs physical \\
Response quality & Action vs a failure to act \\
Immediacy & Direct vs indirect \\
Visibility & Overt vs covert \\
Instigation & Unprovoked vs retaliatory \\
Goal direction & Hostile vs instrumental \\
Type of damage & Physical vs psychological \\
Duration of consequences & Transient vs long-term \\
Social units involved & Towards Individuals vs groups \\
& \\
\hline
\end{tabular}


The table above shows that the author analysed a variety of dimensions, different forms of aggression as well as different types of social consequences of aggressiveness. Krahe (2001) explained that the most of the definitions presented in table 1 are self-explanatory, but he underlines importance of clarifying differences between hostile and instrumental aggression. The difference refers to the psychological function of the aggressive behaviour for the actor. The primary motive for the hostile aggression may be the desire to harm another person through an expression of negative feelings. Contrary to that, the main motive for instrumental aggression is to reach an intended goal by means of the aggressive act. The two types of motives for aggressive behaviour may frequently coexist and that is a main reason why children express the variety of aggression dimensions as well as suffer different types of social consequences of aggressiveness. Essau and Conradt (2004) developed a typology of aggressive behaviour explaining different types of aggressive behaviour such as:

Open aggression defined as open confrontation associated with physical violence, such as physical fighting, terrorizing others, the use of weapons, etc.

Hidden aggression can be defined as acts that take place in secret like stealing, running away from school or home, setting something on fire. Shy children and children with less family emotional support are more prone to such acts.

Reactive aggression is behaviour that occurs in response to some external stimulus, event, or behaviour. The external stimulus very often does not pose a real danger to a child but often child's perception about situation or event is completely different. Children expressing reactive aggression are very often children with underdeveloped skills for emotional and behaviour control. Development of reactive aggression is connected with parenting styles, exposure to violence as well as social and economical factors in the family.

Proactive aggression is the use of aggressive behaviour as an instrument to achieve a certain goal. Children with proactive aggression assume that aggressiveness is supposed to bring about better status in their respective peer community.

Relational aggression is aggression aimed at destroying relations, relationships, or friendship. One of the examples of relational aggression is peer exclusion. Children, victims of relational aggression, are not able to meet basic needs for friendship, they feel unhappy and desperate, and they often react impulsively.

Instrumental and hostile aggressions are two subtypes of aggression that com- 
monly occur together. These types of aggression include aggressive behaviour in which the reward for the aggressor is the victim's pain and the harm that he or she inflicts upon the victim.

In order to learn about teachers' perceptions of the types of aggressive behaviour prevalent in children in $\mathrm{BiH}$, we have used the above mentioned Essau and Conradt (2004) typology of aggressive behaviour as base line for development of assessment scale of teachers' perceptions (see table number 3).

Antisocial behaviour that includes certain kind of aggressive behaviour can occur and disappear again during a child's development. According to Achenbach (1991), about $50 \%$ of parents report that their preschool children steal, lie, disobey, or destroy property. However, studies have shown that children who were very physically aggressive during early childhood continued to show significant aggressive behaviour later in development. Longitudinal studies show a considerable stability and sustainability in physically violent behaviour (Mash and Wolfe, 2010).

Some forms of aggressive behaviour in early childhood development are to some extent "normal." In early interpersonal conflicts, children use this behaviour to learn social strategies for building their position in their environment or to meet their needs. The period from infancy to when a child starts crawling include temper tantrums that are caused by a feeling of bodily discomfort, desire for attention or food, defecating, etc. Very often these forms of aggression appear along with a child's difficulty with sleeping or eating. After the first year of life, instrumental forms of aggression are often associated with taking toys from other children or frustration caused by unfamiliar situations or people. With increasing mobility, the child may exhibit hyperactive behaviour which increases the risk of later aggressive behaviour such as rejecting authority. Lack of self-control in early development and the presence of stressful situations are often the cause of attacks of rage which culminate at the age of three and a half. In the period between three and five years physical aggression decreases in most children because children of this age increase the ability to self-regulate and speech development also reduces the need for aggressive behaviour in conflict resolution. During middle childhood, physical aggression is reduced and more deliberate, while reactive and hostile relational aggression more frequently occurs. Older children are better able to identify the aggressive intentions of others, and they are more prepared to react to them. These changes in the development of aggression are related to children's increasing cognitive abilities, which include, among other things, the development of verbal skills, divergent thinking and emotional intelligence. Krahe (2001) stated that, according to Crick and Grotpeter (1995) and Rys and Bear (1997), in the early school years, gender differences in ag- 
gression become apparent. Boys generally show higher levels of physical aggression than girls. Girls, however, show both verbal aggression (swearing, name calling) and relational aggression, like peer exclusion and gossiping, to a substantial degree.

When differentiating between 'normal' aggression that is part of growing up and 'abnormal' aggressive behaviour one should have in mind the following criteria: (1) considerable deviation from the normal developmental aggression for specific ages, (2) quantitative differences related to frequency, intensity, and duration of aggressive behaviour, (3) the extent to which aggressive behaviour disrupts various aspects of a child development, such as academic success, communication with peers, and speech development, (4) the influence of aggressive behaviour on the child's environment (Essau and Conradt 2004, Moeler 2001).

Psychological theories deal with the development of aggressive behaviour in children. Some theories, such as behavioural theory, social learning theory, the frustration-aggression hypothesis, the Freudian theory of drives, and models of 'anti-social activities,' give us a framework for understanding this important developmental issue. Each theory emphasises a different factor that can contribute to the development of aggressiveness (Tahirović, 2011).

According to Delfos (2008), Francis Galton and Charles Darwin argued that inheritance and environmental factors influence a child's development. Today it is quite clear that both these factors play a significant role and can be viewed on a continuum where it is difficult to determine when the influence of nature is reduced and when influence of environmental factors are increased, or vice versa. A third important factor is the child's development of its central nervous system that improves its functionality throughout the growing up (Delfos, 2008).

Some risk factors for the development of aggressive behaviour can be sub-grouped: genetic and familial factors are related to inheritable traits that determine individual predisposition. We should include factors of temperament in this subgroup, such as emotional and motor skills, readiness to react, and self-regulation. Parent-child interaction and parental education styles determine the level of a child's emotional development, sense of security, capacity for self-control and confidence. Therefore, this factor may also indirectly contribute to the development of aggressive behaviour in children.

Social cognition, the ability to assess one's social environment, plays a very important role in the development of aggressive behaviour. This factor is related to the central nervous system's maturation and children's enhanced cognitive abilities. Children with aggressive behaviour more frequently assess their environment as 
hostile and often wrongly assess their own behaviour; they are often not aware that their behaviour is unsuitable (Essau and Conradt 2004). Poor skill to assess and apply non-verbal cues in communication, something which may be related to social intelligence, is also a significant factor in the development of aggressive behaviour.

The socio-economic status of the family in which the child grows up may not, by itself, be directly linked to the development of aggressive behaviour, but may reflect and support other risk factors. Interpersonal influences within the family or peer group or membership in a particular group is a significant variable primarily for the development of interpersonal relationships, which then may directly or indirectly determines the way how children treat others.

Nowadays, we more and more often encounter media violence, in movies, on television, in music, and video games. It is likely that such mass media can influence the development of aggressive behaviour such that children and young people are de-sensitised to aggressive behaviour. Even more, children, as those who learn through models, identify themselves with aggressive heroes. Cultural factors can significantly determine to what degree aggressive behaviour is 'allowed' and to what degree certain behaviour violates social norms. Some cultures and traditions tolerate more aggressive behaviour, especially when it comes to gender, race or social milieu.

\section{Study Methods}

The aim of this research was to examine teachers' perception of the types of aggressive behaviour as well as to find out the causes for the development of aggressiveness in school-age children in Bosnia and Herzegovina ( $\mathrm{BiH})$ from the teacher's point of view. In order to define and classify the types of aggressive behavior in school age children in $\mathrm{BiH}$ we decided to use the descriptive method. In order to understand aggressive phenomena and to identify their cause(s), we have used the explanatory method. We also did a theoretical analysis to understand different perspectives on aggression, theories that explain the causes for the development of aggressiveness as well as types of aggressive behaviour. Research findings on similar studies are also presented and taken into the considerations.

Our sample in quantitative analyses included a total of 168 teachers working in primary schools. The representation of the total sample included $86.5 \%(n=144)$ women and $14.5 \%(n=24)$ men. The participants for the survey were recruited in primary schools. Selection of participants was done through a simple random sampling. Each teacher in the selected schools had an equal chance of being included in the research. The teachers were informed of the aim of study and our 
commitment to follow ethical research principles. Prior to submitting assessment scales to the participants, we organized pilot testing and discussion. Minor terminological corrections were made after pilot testing. The assessment scales were completed anonymously and teachers took around 20 minutes to answer all the items.

Two instruments were used: (1) an assessment scale of teachers' perceptions of aggressive behavioural types and (2) an assessment scale of the causes of the development of aggressive behaviour in school age children from teacher's point of view. The scales were developed for the purposes of this study and they are connected to the theoretical framework of the research problem.

The assessment scale for teachers' perceptions of types of aggressive behaviour includes a six-item survey and a three-point Likert-scale where 1 is not at all, 2 are often and 3, unsure. The items represent a typology of aggressive behaviour noted by Essau and Conradt (2004). Each item has explanation of the type of aggressive behaviour with aim of avoiding possible terminological misunderstandings. We established the reliability coefficient of the scales in the amount of 0.75 , using the Guttman-Nicewander measure of reliability.

The assessment scale for teacher's perceptions of the causes of aggression is a 12-item survey with again a three-point Likert-scale where 1 is disagree, 2 is unsure and 3 , agree. The scale consists of a list of possible causes for the development of aggressive behavior that follow the causes of aggression presented in a variety of scientific theories. The teachers expressed their perceptions about possible causes of aggressiveness via their level of agreement with the statement. We established the reliability coefficient of the scales in the amount of 0.78 , using the Guttman - Nicewander measure of reliability.

The starting hypotheses of this study are: Reactive and relational aggression are the most frequent types of aggressive behaviour in school-age children from a teacher's perception; Interpersonal influences within the family are the most common causes of aggressive behaviour in school-age children from a teacher's point of view. The fieldwork occurred in Sarajevo, Mostar and Tuzla, three cities in Bosnia and Herzegovina. Data used for this paper was gathered in 2014.

\section{Study Findings}

The teachersarein the position to observechildren'sbehaviour in theschool. Webelieve that assessment of teachers' perceptions on the most common types of aggressive behaviour can be valuable data for describing types of aggressive behaviour most often present in school-agechildren in $\mathrm{BiH}$. The findings are presented in the following table: 
Table 2 Teacher's perceptions of the most common types of aggressive behaviour in school-age children

\begin{tabular}{|c|c|c|c|c|}
\hline & \multicolumn{4}{|c|}{ Degree exhibited } \\
\hline $\begin{array}{l}\text { Type of aggressive } \\
\text { behaviour }\end{array}$ & Not at all & Often & Unsure & Total \\
\hline $\begin{array}{l}\text { Open aggression } \\
\text { (open confrontation } \\
\text { associated with phys- } \\
\text { ical violence, such as } \\
\text { physical fighting, ter- } \\
\text { rorizing others, the } \\
\text { use of weapons, etc.) }\end{array}$ & $\begin{array}{l}24 \\
14.3 \%\end{array}$ & $\begin{array}{l}138 \\
82.1 \%\end{array}$ & $\begin{array}{l}6 \\
3.6 \%\end{array}$ & $\begin{array}{l}168 \\
100 \%\end{array}$ \\
\hline $\begin{array}{l}\text { Hidden aggression } \\
\text { (actions that take } \\
\text { place in secret like } \\
\text { stealing, running } \\
\text { away from school } \\
\text { or home, setting } \\
\text { fire to something) }\end{array}$ & $\begin{array}{l}66 \\
39.3 \%\end{array}$ & $\begin{array}{l}90 \\
53.6 \%\end{array}$ & $\begin{array}{l}12 \\
7.11 \%\end{array}$ & $\begin{array}{l}168 \\
100 \%\end{array}$ \\
\hline $\begin{array}{l}\text { Reactive aggression } \\
\text { (behaviour that occurs } \\
\text { in response to some } \\
\text { external stimulus, } \\
\text { event, or behaviour). }\end{array}$ & 0 & $\begin{array}{l}144 \\
85.7 \%\end{array}$ & $\begin{array}{l}24 \\
14.3 \%\end{array}$ & $\begin{array}{l}168 \\
100 \%\end{array}$ \\
\hline $\begin{array}{l}\text { Proactive aggres- } \\
\text { sion (the use of ag- } \\
\text { gressive behaviour } \\
\text { as an instrument to } \\
\text { achieve a certain goal) }\end{array}$ & 0 & $\begin{array}{l}168 \\
100 \%\end{array}$ & 0 & $\begin{array}{l}168 \\
100 \%\end{array}$ \\
\hline $\begin{array}{lr}\text { Relational aggres- } & \text { (aggression } \\
\text { sion } & \text { (agmed at destroying } \\
\text { aimed } & \text { relations, relation- } \\
\text { ships, or friendship) }\end{array}$ & $\begin{array}{l}6 \\
3.6 \%\end{array}$ & $\begin{array}{l}144 \\
85.7 \%\end{array}$ & $\begin{array}{l}18 \\
10.7 \%\end{array}$ & $\begin{array}{l}168 \\
100 \%\end{array}$ \\
\hline $\begin{array}{l}\text { Instrumental and hos- } \\
\text { tile aggression (two } \\
\text { subtypes of aggres- } \\
\text { sion that commonly } \\
\text { occur together. These } \\
\text { types of aggression } \\
\text { include aggressive } \\
\text { behaviour in which } \\
\text { the reward for the ag- } \\
\text { gressor is the victim's } \\
\text { pain and the harm } \\
\text { that he or she inflicts } \\
\text { upon the victim.) }\end{array}$ & $\begin{array}{l}60 \\
35.7 \%\end{array}$ & $\begin{array}{l}78 \\
46.4 \%\end{array}$ & $\begin{array}{l}30 \\
17 . \%\end{array}$ & $\begin{array}{l}168 \\
100 \%\end{array}$ \\
\hline
\end{tabular}


In our study, teachers most often recognized proactive aggressive behaviour that children use for the achievement of certain goals. All teachers in our sample identified proactive aggression in children, assuming that children use aggressiveness to create their position in their peer community.

In our previously conducted preliminary study of preschool children we had similar findings (Tahirović, 2013b). We have explained these findings as follows: children in the preschool period have not cognitively and emotionally reached such a level of development to achieve their goals using negotiation strategies or other less aggressive verbal methods of conflict resolution. For school-age children, however, we expected that emotional self-regulation and language skills that could be used in problem solving strategies would already be developed, However, from this study's findings, we can assume that such less aggressive strategies have not yet been applied from teacher. The following findings confirmed previous assumption since the table shows that teachers also identified reactive and relational aggression as the most often expressed types of aggressiveness among school- aged children.

Teachers observation that reactive aggression often occurs as well, suggests that the environment and climate in which the child grows up may encourage the development of aggressive behaviour. A sense of uncertainty usually leads to a cognitive assessment that one is in danger, therefore the child will more likely (re)act aggressively. Children often behave aggressively in an environment permeated by aggressive behaviour: they learn these behaviours from each other and apply them to protect themselves against potential hazards. In conclusion we can assume that the presence of proactive aggression may trigger reactive aggression, is most often noticed in school-age children, in accordance with teachers' perception.

As presented in the following section, the teacher's points of view confirm what has been already proposed by several authors. Aggressive children are rejected by their peers from as early as age six, and rejection is associated with a subsequent increase in aggression. The more a child's behaviour is dominated by aggression, the less he or she displays non-aggressive behaviour. Aggressive children are socially isolated from their non-aggressive peers so they are likely to associate with other aggressive peers, which further promote aggressive behaviour (Krahe, 2001).

Young children with poor emotional regulation are more likely to be fearful or to respond withirritation toothers ' distress, or reactangrilyor aggressivelywhenfrustrated. They have difficulties with adjusting to classroom routines as well as in communication with teachers and peers. When emotional self regulation has developed well, young people gain a feeling of being in control of their emotional experience (Berk, 2009). 
The fact that teachers observe relational aggression (85.7\%) in school-aged children came as no surprise to us. Increase of relational aggression among schoolaged children can be explained by children's cognitive ability to comprehend importance of friendship. From middle childhood physical aggression decreases and becomes more deliberate and planned, while aggression aimed at destroying relationships or friendship $\neg$ is more frequently used to induce emotional harm.

Thus our hypothesis that teachers often perceive reactive and relational aggression is partly confirmed since teachers recognized proactive aggression as the most frequently displayed types of aggressive behaviour, and reactive and relational aggression as secondary.

We cannot ignore the fact that more than half of teachers in our sample often acknowledged both open and hidden aggressive behaviour in children. Having in mind that hidden aggression takes place in secret and open aggression is associated with physical violence, and in line with previously explained findings, we can emphasize the following; teacher's perception of the most common types of aggressive behaviour in school-age children indicates presence of variety types of aggressive behaviour expressed in different level but still very often used among children. The findings that teachers often do not recognize instrumental and hostile aggression or are not certain (17\%) of its presence, cannot lead to the conclusion that such kinds of aggressiveness do not exist, but rather that it is difficult to detect these types of aggression. The victims of such kind of violence are most often shy and withdrawn children, which usually do not report about violence that they are exposed to. In this study, we were interested in teachers' perceptions of the causes of aggressive behaviour in children. The results shown in Table 3 suggest that teachers perceive a wide range of causes of aggressive behaviour:

Table 3. Teachers' perceptions of the causes of aggressive behaviour in children

\begin{tabular}{|l|l|l|l|l|}
\hline \multirow{2}{*}{ Statement } & \multicolumn{4}{|c|}{ Level of agreement } \\
\cline { 2 - 5 } & Disagree & Unsure & Agree & Total \\
\hline $\begin{array}{l}\text { Aggressive behaviour } \\
\text { can be learned, main- } \\
\text { tained, or changed } \\
\text { through a process of } \\
\text { observation, classical, } \\
\text { and operant condi- } \\
\text { tioning. }\end{array}$ & $0 \%$ & 24 & 144 & 168 \\
\hline $\begin{array}{l}\text { Aggressive behaviour } \\
\text { is acquired through } \\
\text { learning: by observ- } \\
\text { ing and imitating. }\end{array}$ & $0 \%$ & $14.3 \%$ & $85.7 \%$ & $100 \%$ \\
\hline
\end{tabular}




\section{S. Tahirović}

\begin{tabular}{|c|c|c|c|c|}
\hline $\begin{array}{l}\text { Aggressive behav- } \\
\text { iour is the result of } \\
\text { frustration that arises } \\
\text { in situations where a } \\
\text { child or young person } \\
\text { is prevented or hin- } \\
\text { dered from obtaining } \\
\text { a specific goal }\end{array}$ & $\begin{array}{l}12 \\
7.1 \%\end{array}$ & $\begin{array}{l}14 \\
8.9 \%\end{array}$ & $\begin{array}{l}142 \\
84.5 \%\end{array}$ & $\begin{array}{l}168 \\
100 \%\end{array}$ \\
\hline $\begin{array}{l}\text { Aggressive behaviour } \\
\text { occurs as a combi- } \\
\text { nation of internal } \\
\text { impulses (anger, ani- } \\
\text { mosity) and external } \\
\text { stimuli or triggers } \\
\text { that indicate possible } \\
\text { aggression }\end{array}$ & $\begin{array}{l}6 \\
3.6 \%\end{array}$ & $\begin{array}{l}0 \\
0 \%\end{array}$ & $\begin{array}{l}162 \\
96.4 \%\end{array}$ & $\begin{array}{l}168 \\
100 \%\end{array}$ \\
\hline $\begin{array}{l}\text { Instincts are the basis } \\
\text { of aggression. }\end{array}$ & $\begin{array}{l}12 \\
7.3 \%\end{array}$ & $\begin{array}{l}48 \\
28.5 \%\end{array}$ & $\begin{array}{l}108 \\
64.2 \%\end{array}$ & $\begin{array}{l}168 \\
100 \%\end{array}$ \\
\hline $\begin{array}{l}\text { Antisocial tendencies } \\
\text { (temperament, en- } \\
\text { vironmental factors, } \\
\text { the role of parents } \\
\text { and their way of disci- } \\
\text { plining a child, and } \\
\text { peer pressure) are the } \\
\text { cause of aggressive } \\
\text { behaviour. }\end{array}$ & $\begin{array}{l}0 \\
0 \%\end{array}$ & $\begin{array}{l}12 \\
7.1 \%\end{array}$ & $\begin{array}{l}156 \\
92.8 \%\end{array}$ & $\begin{array}{l}168 \\
100 \%\end{array}$ \\
\hline $\begin{array}{l}\text { Genetic factors, } \\
\text { primarily hereditary } \\
\text { traits cause aggressive } \\
\text { behaviour in children }\end{array}$ & $\begin{array}{l}12 \\
7.1 \%\end{array}$ & $\begin{array}{l}42 \\
25.2 \%\end{array}$ & $\begin{array}{l}114 \\
67.8 \%\end{array}$ & $\begin{array}{l}168 \\
100 \%\end{array}$ \\
\hline $\begin{array}{l}\text { Poverty is a cause of } \\
\text { aggressive behaviour } \\
\text { in children. }\end{array}$ & $\begin{array}{l}78 \\
46,4 \%\end{array}$ & $\begin{array}{l}18 \\
10,7 \%\end{array}$ & $\begin{array}{l}72 \\
42.85 \%\end{array}$ & $\begin{array}{l}168 \\
100 \%\end{array}$ \\
\hline $\begin{array}{l}\text { Interpersonal } \\
\text { influences within the } \\
\text { family are the cause of } \\
\text { aggressive behaviour } \\
\text { in children }\end{array}$ & $\begin{array}{l}0 \\
0 \%\end{array}$ & $\begin{array}{l}24 \\
14.2 \%\end{array}$ & $\begin{array}{l}144 \\
85,7 \%\end{array}$ & $\begin{array}{l}168 \\
100 \%\end{array}$ \\
\hline $\begin{array}{l}\text { Membership in a } \\
\text { particular peer group } \\
\text { determines the devel- } \\
\text { opment of aggressive } \\
\text { behaviour in children. }\end{array}$ & $\begin{array}{l}6 \\
3.6 \%\end{array}$ & $\begin{array}{l}24 \\
14.2 \%\end{array}$ & $\begin{array}{l}138 \\
82.2 \%\end{array}$ & $\begin{array}{l}168 \\
100 \%\end{array}$ \\
\hline $\begin{array}{l}\text { Mass media (movies, } \\
\text { television, music, } \\
\text { video games) directly } \\
\text { affect the develop- } \\
\text { ment of aggressive be- } \\
\text { haviour in children. }\end{array}$ & $\begin{array}{l}0 \\
0 \%\end{array}$ & $\begin{array}{l}6 \\
3.6 \%\end{array}$ & $\begin{array}{l}162 \\
96.4 \%\end{array}$ & $\begin{array}{l}168 \\
100 \%\end{array}$ \\
\hline $\begin{array}{l}\text { Culture and traditions } \\
\text { affect the develop- } \\
\text { ment of aggressive be- } \\
\text { haviour in children. }\end{array}$ & $\begin{array}{l}90 \\
53.5 \%\end{array}$ & $\begin{array}{l}44 \\
26.3 \%\end{array}$ & $\begin{array}{l}34 \\
20.2 \%\end{array}$ & $\begin{array}{l}168 \\
100 \%\end{array}$ \\
\hline
\end{tabular}


A large percentage of teachers agreed with the majority of the possible causes of aggressive behaviour on the survey. The data shows that teachers understand that a wide variety of causes may affect the development of aggression. Almost all the participants' responses were aligned with Berkovitz's (1965) revised frustration-aggression hypothesis that says aggressive behaviour occurs in a combination of internal impulses and external stimuli. Feelings of anger and animosity can be triggered by external stimuli and provoke aggressiveness, as confirmed by $96.4 \%$ of teachers in our sample.

Alsointeresting istheobservation ofalmostallteachers(162 outof 168) thatmassmedia can be a cause of aggressive behaviour in school children. Feldman's (2009) evidence supports the notion that observing media violence can lead to a greater readiness to act aggressively. For example, children who play video games containing violence may be more likely to behave aggressively (Anderson et al., 2004). The teachers' perceptions that watching TV or playing video games with violent contents may play significant role in aggressive behaviour development are in the line with notion that exposure to more violent content might make children less sensitive on violence in every day.

In addition, we can see from the data presented in table 3 that from the teachers' perceptions, environmental factors can play a crucial role in the development of aggressiveness in children. $92.8 \%$ of teachers agreed with the statements that: aggressive behaviour can be acquired through learning, observing and imitating models. Social learning approaches to aggression emphasize how social and environmental conditions teach children to be aggressive. In accordance with Feldman (2009), these teachers think that exposure to aggressive models leads to increased aggression, particularly if the observers are themselves angry; feel insulted, or frustrated what is in line with teacher's point of view in our research findings. Even more strikingly, 85.7\% teachers believe that aggressive behaviour can be learned, maintained, or changed through a process of observation, classical, and operant conditioning. Teachers who participated in this research found a correlation between family situation with the development of aggressiveness in children, and many of them (85.7\%) agreed that interpersonal influences within the family can cause of aggressive behaviour in children.

More than half of the teachers surveyed expressed their disagreement that poverty can be a cause of aggressive behaviour in school children. This observation is to be expected since much previous research has underlined that there may not be a direct link between the socio-economic status of the family in which the child grows up and the development of aggressive behaviour; but that this may reflect or support other risk factors. An even greater number of the surveyed teachers (53.5\%) expressed their disagreement with the statement that culture and traditions influence the development of aggressive behaviour in children. Just $20.2 \%$ of teachers 
connected culture and traditions with aggressive behaviour. As we explained before, cultural factors determine sensitivity to aggressive behaviour, while social norms define acceptable behaviour. Therefore, teachers did not see culture as a direct cause for aggressiveness or its development. Teachers do not believe that genetic factors or instincts influence aggressiveness. The $25 \%$ and $28.5 \%$ or teachers who participated in this research are not sure about this issue. This finding may be explained by the fact that teachers do not possess information about family history, so they have difficulty connecting a child's genetic predisposition with their aggressive behaviour.

Our hypothesis that interpersonal influences within the family are the most common cause of aggressive behaviour in school-age children, from the teacher's point of view, has been partly confirmed. The theoretical background of our hypotheses was the notion that dysfunctional families with marital problems and stress and the use of physical punishment can make children feel insecure; if they assess this environment as being hostile and learn aggressive behaviour from their parents, children may model this outwardly. The teachers perceived interpersonal influences within the family as important but not the most important cause of the development of aggression in children. The fact that teachers often also perceived other causes in the proposed list indicates that they grasp the multiplicity of causes contributing to the development of aggression in children.

\section{Conclusion}

Aggressiveness is not just a behaviour that threatens physical harm to others but one that influences a child's development. Aggressive children often grow up in difficult family situations; they develop some aggressive behaviour in their early development and experience difficulty in school.

School bullying includes different types of aggressive behavior that occurs in an educational setting, mostly among peers. The nature of bullying can be physical, sexual, verbal or emotional. The main characteristics of bullying are: intention to harm peers; psychological distress of victim; bullying is persistent and occurs in multiple times. Most importantly, bullying is motivated by perceived benefit of aggressive behavior which represents one of the main characteristics of instrumental aggression.

Holt et al (2007) stated that bullying is a highly prevalent phenomenon with a harmful and long-lasting effect on victims and a negative impact on school climate. Many statistics in different countries suggest that the majority of students will experience bullying at some point in their school time. In the early 21 st century, increasing attention has been given to the importance of teachers and parents 
understanding and recognizing the signs of bullying. Our research regarding teachers' perceptions of the most common types of aggressive behaviour as well as the causes of aggressive behaviour in children aims to increase understanding of the development of aggressiveness in school-age children in Bosnia and Herzegovina.

The prevalence of bullying is not widely studied in Bosnia and Herzegovina. A cross-sectional study (Černi, Rumboldt, 2008) of bullying among school children in postwar Bosnia and Herzegovina finds that $\neg$ every sixth student (16.4\%) experienced at least one form of bullying almost every day, while $7.0 \%$ of pupils constantly bullied other children. Sixth-eighth graders were more often bullies than 4th-5th graders. Girls were most often victims of bullying, while boys were most often bullies.

The quantitative study findings showed that teachers usually noticed proactive as well as reactive and relational aggression in school age children. However, more than $80 \%$ of participants also noticed open aggressiveness in children. Our research proved that teachers recognise different types as well as levels of aggressive behaviour in school children. We have been focused on the types as well as causes of aggressiveness in school-age children; however from research findings it is easy to conclude that teachers understand the fact that aggressive behaviour in different types is very often common among children. They do understand that bullying is widely present among children.

From the teachers' point of view, children do communicate in an aggressive manner in everyday life and very often they use aggressiveness as an instrument to reach a certain goal. This finding led us to the conclusion that aggressive children have cognitive awareness that aggressiveness is an effective tool for communication with peers. Teachers believed that a combination of internal impulses and external stimuli plus the influence of media trigger aggressiveness. They also believed that the role of parents and their ways of disciplining children can be a second important cause. Interpersonal influences within the family are an important factor according to teachers, but over these, they prioritized personality characteristics and external environmental factors.

The fact that Bosnia and Herzegovina in this post-war transitional period faces many political and economical challenges that create uncertain school environment, and given the finding that environmental factors can play a crucial role in development of aggressiveness in children (in accordance with teachers' perception), makes this research an important source of information for understanding the current situation in regard to bullying. In accordance to the longitudinal studies of Mash and Wolfe (2010), considerable stability and sustainability in physically violent behaviour has been established. Studies have shown that children who were very physically aggressive during early childhood continued to show significant aggressive behaviour later 
in development. Our research findings indicate the likelihood that young people in Bosnia and Herzegovina might continue to use aggressiveness in their future life.

We believe that the qualitative study findings presented in this article significantly increase the knowledge and understanding of the development, causes, and types of aggressive behaviour in children in $\mathrm{BiH}$. However, aggressive behaviour is not just inappropriate behaviour, but a very important factor that can influence a child's development. On the other hand, development of aggressive behaviour is related to the child's psychological development, especially in the areas of emotional, social and cognitive development. Thus, we believe that the qualitative research that we plan to conduct in the near future will help us to further understand and explain the following research question: why do many children develop aggressive behaviour in $\mathrm{BiH}$ ? The quantitative and qualitative data will serve as the baseline for the development of a plan of action with the aim of reducing risk factors for the development of aggressive behaviour among children in Bosnia and Herzegovina

\section{References}

Achenbach, T.M. 1991. Manual for the Child Behaviour Checklist / 4-18. Burlington: University of Vermont.

Anderson, C., Funk, J. B., Griffiths, M.D. 2004. Contemporary Issues in Adolescence Video Game Playing: Brief Overview and Introduction to the Special Issue. Journal of Adolescence, 27, 1-3. Bandura, A. 1977. Self Efficacy: Toward a Unifying Theory of Behavioral Change. Psychological Review, 84, 191-215.

Banjanin-Duričić, N. 1998. Udarac po duši - sociološka studija zlostavljanja dece u porodici. Belgrade: Institut za kriminološka i sociološka istraživanja i Jugoslovenski centar za prava deteta. Bar-On, R. 2006. The Bar - On Model of Emotional-Social Intelligence (ESI). Psicothema, 18, 13-25.

Baron, R.A., Kalsher, M.J. 2008. Psychology: From Science to Practice. Boston: Pearson. Bartol, C.R. 1995. Criminal Behavior: A Psychological Approach. Englewood Cliffs, NJ: Prentice Hall.

Bennett, P. 2008. Abnormal and Clinical Psychology: An Introductory Textbook. New York: McGraw Hill.

Bennett, P. 2006. Abnormal and Clinical Psychology. Buckingham: Open University Press.

Berk, L.E. 2009. Child Development. Boston: Pearson.

Broidy, L.M., et. al. 2003. Developmental Trajectories of Childhood Disruptive Behaviours and Adolescent Delinquency. Developmental Psychology, 39, 222-245.

Burns, G.L., et. al. 1997. Internal Validity of Disruptive Behaviour Disorder Symptoms: Implications from Parent Ratings for a Dimensional Approach to Symptom Validity. Journal of Abnormal Child Psychology 25, 307-319,

Connor, D.F. 2002. Aggression and Antisocial Behaviour in Children and Adolescents, New York: Guilford Press.

Cook, J.L., Cook, G. 2009. Child Development, Principles and Perspectives, Boston: Pearson.

Černi Obrdalj, E., Rumboldt, M. 2008. Bullying Among School Children in Postwar Bosnia and 
Herzegovina: Cross-Sectional Study. Croat Med J; 49:528-535

Davison, G.C., Neal, J.M. 1999. Psihologija Abnormalnog doživljavanja i ponašanja. Zagreb: Naklada Slap.

DeHart, G., Sroufe, L.A., Cooper, R.G. 2004. Child Development, Its Nature and Courses. New York: McGraw Hill.

Delfos, M.F. 2004. A Strange World, Autism, Asperger's Syndrome and PDD-NOS. A Guide for Parents, Partners, Professional Carers and People with ASDs. London: Jessica Kingsley.

Delfos, M.F. 2004. Children and Behavioural Problems. Anxiety, Aggression, Depression and

ADHD: A Biopsychological Model with Guidelines for Diagnostics and Treatment. London: Jessica Kingsley .

DSM-V-TR Diagnostic and Statistical Manual of Mental Disorders 2014. Arlington: American Psychiatric Association.

Essau, C.A., Conradt, J. 2004. Agresivnost kod djece i mladih. Zagreb: Naklada Slap.

Feldman, S.R. 2009. Development Across the Life Span. Boston: Pearson.

Holt, M.K., Finkelhor, D., Kantor, G.K. 2007. Multiple victimization experiences of urban elementary school pupils: associations with psychosocial functioning and academic performance. Child Abuse Neglect. 31: 503-515.

Loaber, R., Hay, D. 1997. Key Issues in the Development of Aggression and Violence from Childhood to Early Adulthood, Annual Review of Psychology, 48, 371-410.

Mash, E.J., Wolfe, D.A. 2010. Abnormal Child Psychology, Wadsworth: Cengage Learning.

Morton, C. 2008. Tehnike u dječijoj terapiji. Zagreb: Alineja.

Ross, V., Haith, M.M., Miller, S. A. 2005. Dječija psihologija. Zagreb: Naklada Slap.

Tahirović, S. 2007. Borba protiv nasilja nad djecom iz perspektive prava djece. International Conference on Violence against Children, Sarajevo.

Tahirović, S. 2009. Stavovi djece o vrijednosti roditeljstva. Didaktički putokazi, 51, 17-26.

Tahirović, S. 2010. The Value of Parenting is measured by Love and Support, Bologna University journal Riccerche di Pedagogia e Didarrica. http://rpd.cib.unibo.it/.

Tahirović, S. 2013a. Psihološki razvoj djece i mladih, Sarajevo: International University of Sarajevo. Tahirović, S. 2013b. Preliminarno istraživanje o agresivnim ponašanjima kod djece predškolskog uzrasta, Naučna monografija o suvremenim tokovima u ranom odgoju. Zenica Tahirović, S. 2011. Agresivnost djece, razvojna perspektiva, Tuzla: University of Tuzla. Wenar, C. 2003. Razvojna psihopatologija i psihijatrija, od dojenačke dobi do adolescencije. Zagreb: Naklada Slap. 